\title{
O mercado privado de vacinas no Brasil: a mercantilização no espaço da prevenção
}

\author{
The private vaccines market in Brazil: \\ privatization of public health
}

José Gomes Temporão ${ }^{1}$

\footnotetext{
1 Departamento de

Administração e

Planejamento em Saúde,

Escola Nacional

de Saúde Pública, Fundação

Oswaldo Cruz.

Rua Leopoldo Bulhões 1480,

Rio de Janeiro, $R J$

21041-210, Brasil.

temporao@ensp.fiocruz.br
}

\begin{abstract}
The main objective of this article is to analyze the vaccines market in Brazil, which is characterized as consisting of two segments with distinct practices and logics: the public segment, focused on supply within the Unified National Health System (SUS) and the private segment, organized around private clinics, physicians' offices, and similar private health facilities. The private vaccines market segment, studied here for the first time, is characterized in relation to the supply and demand structure. Historical aspects of its structure are analyzed, based on the creation of one of the first immunization clinics in the country. The attempt was to analyze this segment in relation to its economic dimensions (imports and sales), principal manufacturers, and products marketed. It economic size proved much greater than initially hypothesized. The figures allow one to view it as one of the main segments in the pharmaceutical industry in Brazil as measured by sales volume. One detects the penetration of a privatizing logic in a sphere that has always been essentially public, thereby introducing into the SUS a new space for disregarding the principles of equity and universality.
\end{abstract}

Key words Vaccines Market; Drug Industry; Vaccines

Resumo Este artigo tem como objetivo principal a análise do mercado de vacinas no Brasil, que está caracterizado como composto de dois segmentos com práticas e lógicas distintas: o segmento público voltado para a oferta ao interior do Sistema Único de Saúde (SUS) e o privado que se organiza em torno de clínicas, consultórios e outros espaços privados. O segmento privado, aqui estudado pela primeira vez, é caracterizado em relação à estrutura da oferta e da demanda. Os aspectos históricos de sua estruturação são analisados tomando-se como referência a criação de uma das primeiras clínicas de imunização do país. Busca-se caracterizar este segmento em relação à sua dimensão em termos econômicos (importações e vendas), principais fabricantes e produtos comercializados. Sua dimensão econômica que revelou-se muito superior ao inicialmente aventado. Os números obtidos permitem considerá-lo como um dos principais segmentos de mercado da indústria farmacêutica no país, em termos de volume de vendas. Detecta-se a penetração de lógicas privatizantes em um espaço que sempre foi marcadamente público, com isso introduzindo no SUS um novo espaço de quebra dos princípios da eqüidade e universalidade.

Palavras-chave Mercado de Vacinas; Indústria Farmacêutica; Vacinas 


\section{Introdução}

No campo das políticas públicas - considerando as duas últimas décadas - a saúde foi um setor em que se experimentaram mudanças significativas. A chamada reforma sanitária brasileira expressada (de modo limitado) na constituição do Sistema Único de Saúde (SUS), é o marco dessas mudanças. Ainda assim, os princípios da universalização, da igualdade, da descentralização, do controle social, do acesso aos serviços (entre outros), apesar de alguns avanços, estão longe de terem sido alcançados.

Neste contexto a questão dos insumos (medicamentos, imunobiológicos, hemoderivados e equipamentos médico-hospitalares) adquire importância crescente. Ou seja, a garantia do direito à saúde não pode prescindir da garantia do acesso aos insumos necessários para viabilizá-lo.

Vacina como objeto de estudo pode ser abordado de diferentes óticas, privilegiando distintas dimensões analíticas, podendo-se citar: a política, de saúde pública, histórica, de pesquisa e desenvolvimento, clínica, de direitos do consumidor, econômica e gerencial. A maior parte dos estudos desenvolvidos neste campo aborda principalmente os aspectos relacionados à análise epidemiológica, estudos clínicos, tecnológicos, avaliação de políticas em relação ao acesso e cobertura, além de estudos de custo-benefício.

Sobre o setor de insumos há no país uma produção acadêmica razoável, mas concentrada ao campo da política de medicamentos e indústria farmacêutica. Publicações mais recentes, como a organizada por Negri \& Giovanni (2001), ampliam o foco, incorporando análises sobre o setor de equipamentos. Estudos acadêmicos realizados sobre o tema dos imunobiológicos, especificamente abordando a produção e o consumo de vacinas no Brasil, de uma perspectiva de política de Estado e de saúde, são escassos (Gadelha \& Temporão, 1999).

Embora este segmento não tenha peso econômico significativo dentro das despesas globais do setor ou mesmo em comparação com as demais classes terapêuticas - já que o mercado mundial de medicamentos está estimado em cerca de 300 bilhões de dólares, e o de vacinas atingiu apenas sete bilhões de dólares em 2000 (Greco, 2002) - as perspectivas dadas pelos avanços tecnológicos recentes, pelo seu potencial de crescimento e pela importância das vacinas como poderoso instrumento de redução de morbidade e mortalidade, merecem análises que abordem seu impacto na dinâmica do setor saúde.
São escassos os estudos sobre esta área de atuação do Estado, sobre sua especificidade e singularidades. Estas, determinadas pelas características dos bens produzidos (vacinas) historicamente ligados a uma concepção tradicional de saúde pública não considerando questões do mercado e da competição.

No Brasil, ao interior da política de saúde, desenvolvem-se durante as décadas de 70 a 90 dois programas que irão, em conjunto, criar as condições necessárias e suficientes à estruturação de um mercado maduro para as vacinas: o Programa Nacional de Imunizações (PNI) e o Programa Nacional de Auto-suficiência em Imunobiológicos (PASNI).

A continuidade dada ao longo dos anos à execução da estratégia das campanhas nacionais de vacinação, ao lado da expansão acentuada da rede básica de serviços, ocorrida a partir de meados dos anos 80 , estabelecem as bases de uma demanda crescente e consistente para as vacinas, e provêem a base operacional necessária para seu desenvolvimento.

Constituiu-se nesse processo um espaço eqüitativo e universal do ponto de vista do acesso a este tipo de oferta. Dentro de um sistema historicamente desigual no acesso a bens e serviços de promoção e recuperação da saúde, o Estado constrói um segmento de igualdade do ponto de vista do acesso às vacinas disponíveis no PNI. Este fato estabelece a definição dos limites deste segmento do mercado de vacinas: espaço público onde a população tem acesso aos produtos definidos como essenciais pelo próprio Estado, para o controle de doenças consideradas estratégicas. Mas, como da perspectiva do Estado, a essencialidade do que deve ser garantido à população envolve aspectos técnicos, políticos e financeiros, abre-se no interior do mercado um outro espaço que se organiza obedecendo a outra lógica. Setores da população buscam neste outro espaço, organicamente vinculado ao setor privado de oferta de cuidados em saúde, e obedecendo a um sentido particular, uma atenção diferenciada e o acesso a produtos da fronteira tecnológica que o Estado não oferece ou, quando oferece, o faz parcialmente.

A partir do final dos anos 80 , surge um forte vetor de mudanças no mercado com o lançamento de novos produtos que aperfeiçoam vacinas já existentes ou que passam a oferecer proteção até então indisponível contra determinados agravos. Com o surgimento dessas novas vacinas, frutos do desenvolvimento tecnológico, tem início uma defasagem entre a oferta garantida pelo Estado, as necessidades do controle de doenças anteriormente não preve- 
níveis por imunização e a demanda da sociedade pelo acesso aos novos produtos. Como o PNI não garante o acesso da população a esse conjunto de produtos, estabelecem-se iniciativas privadas voltadas para o atendimento específico desta demanda. Estavam assim criadas as condições para a estruturação de um novo segmento neste mercado: o da comercialização privada de vacinas e, com ele, o surgimento de um novo espaço de desigualdade até então inexistente: o do acesso diferenciado às modernas vacinas. Estes fatos criam novas possibilidades no campo da prevenção de doenças e novas perspectivas para a dinâmica do mercado, com a estruturação de práticas comerciais específicas.

Espaço desconhecido e desconsiderado por gestores de políticas públicas e por especialistas, o estudo do segmento privado do mercado de vacinas buscou não apenas o dimensionamento de seu real peso econômico, mas também caracterizá-lo como espaço de transformações importantes que se processam dentro do setor saúde e seu impacto na organização das políticas e práticas assistenciais. Apesar das especificidades que o mercado de vacinas apresenta (oligopólio estatal na produção e hegemonia pública na oferta), que permitem afirmar que este ainda seja um espaço predominantemente público, os resultados obtidos apontam para a penetração das práticas privadas de oferta e consumo de vacinas, neste que sempre foi paradigma da presença estatal no campo das políticas públicas em saúde.

\section{Metodologia}

O estudo desenvolvido para a caracterização do segmento privado apresentou importante grau de dificuldade. Por tratar-se de tema analisado pela primeira vez em nosso país, foi necessária investigação específica que envolveu: o levantamento de informações referentes às importações realizadas; caracterização dos principais produtores deste segmento; dados históricos sobre a oferta, incluindo a forma como se definiram as estratégias de comercialização, entre outras variáveis. Para reconstituir a trajetória e desempenho deste segmento do mercado procedeu-se a levantamento de dados junto a órgãos públicos, laboratórios multinacionais produtores, clínicas de vacinação, empresas distribuidoras de vacinas, sociedades médicas e especialistas. A realização de entrevistas junto a esses vários atores e os dados complementares levantados, revelaram-se de grande valor.

O tratamento dos dados referentes às importações de vacinas pelo segmento privado, esbar- rou em obstáculos metodológicos: tanto as fontes disponíveis para consulta no Ministério da Indústria e Comércio (Sistema Alice) quanto as do Ministério da Fazenda (Sistema de Estatísticas do Comércio Exterior - Sixcomex) apresentavam problemas. Em primeiro lugar, permitiam obter apenas o valor total das importações efetuadas pelo país, não discriminando entre as importações realizadas pelo setor público e pelo privado. Em segundo lugar, apresentavam o total de importações em um tipo de agregação por produtos que não permitia análise referida ao grau ou nível de tecnologia inserida nos diferentes tipos de vacinas. Por fim, não permitiam discriminar as importações realizadas no interior do setor público, por instituições e por níveis de governo.

Para poder proceder ao levantamento dos dados necessários à caracterização deste segmento do mercado, foram utilizados aqueles obtidos junto à Divisão de Estatísticas do Comércio Exterior do Ministério da Fazenda. Para tanto definiu-se o período compreendido entre 1997 e 2001, dado que apenas a partir daquele ano as informações sobre importações de vacinas passaram a ser registradas no Sixcomex.

Levantou-se para o período referido todas as importações realizadas com base em análise dos registros individuais de cada importação onde, entre outras informações, podem-se obter: produto importado por denominação genérica e nome de marca, número de doses, empresa importadora, produtor e valor da transação.

As informações assim obtidas foram complementadas com a realização de entrevistas com uma empresa distribuidora, empresa produtora multinacional, clínicas de vacinação e especialistas.

\section{O complexo médico industrial e a indústria de vacinas: público e privado na dinâmica do mercado}

No Brasil, o conceito de complexo médico industrial (CMI) foi utilizado pela primeira vez por Cordeiro (1980), ao estudar o padrão de consumo de medicamentos no país. Referindo-se ao CMI como determinação fundamental das práticas de consumo de medicamentos, definiu-o enquanto “...a produção e circulação de medicamentos, a organização da prática médica, as formas de intervenção estatal no setor e as práticas concretas de consumo individual... a formação de recursos humanos, as articulações da escola médica com a Indústria Farmacêutica e as relações com o setor de equipamentos" (Cordeiro, 1980:113). 
Segundo Braga \& Silva (2001), existem duas etapas no processo de desenvolvimento da atenção à saúde no país. A primeira denominada de capitalização da medicina, cobre a fase em que o Estado foi o centro do processo de financiamento da ampliação da oferta e demanda aos serviços e bens do setor. A segunda, referida como de "mercantilização da saúde", "é a fase que, no Brasil, se segue à da capitalização da medicina...onde o setor privado vai se autonomizando no financiamento, cuja expressão máxima são os seguros saúde privados, na produção de serviços que já conta com uma base própria de acumulação em expansão...multiplicam-se os tipos de empresas de saúde e o consumidor de serviços se encontra no mercado e não mais diante do serviço público..." (Braga \& Silva, 2001:20).

Este processo, em pleno desenvolvimento no país, encontrava no mercado de vacinas um espaço de singularidade: a persistência do conjunto de práticas preventivas que envolvem a utilização de vacinas como espaço eminentemente público, de caráter universal e equânime. Mantinha-se portanto, posição distinta em relação a outros bens, produtos e serviços inseridos na dinâmica capitalista do complexo industrial da saúde. A introdução da lógica mercantil nesse espaço dá-se com mais intensidade e organicidade frente ao conjunto de práticas do complexo apenas a partir do início dos anos 90. Ou seja, no momento em que o processo de capitalização e mercantilização do sistema de saúde do país já se encontra em fase avançada de seu desenvolvimento. Percebe-se nesse processo uma dinâmica tardia de inserção no processo de mercantilização em curso, que ocorre a partir do momento em que as vacinas se transformam em "uma mercadoria submetida às regras de produção, financiamento $e$ distribuição de tipo capitalista" (Braga \& Silva, 2001:21). Está determinada por dois aspectos fundamentais: pelo desenvolvimento da ciência e da tecnologia ao criar um novo produto com tecnologia de DNA recombinante, rapidamente seguido por outros; e pelo encontro com um crescente e cada vez mais presente setor privado de oferta de serviços médico-hospitalares, onde esse novo segmento se insere. Isso trará consigo a quebra da eqüidade historicamente observada neste espaço das práticas preventivas.

Enquanto na década de 80 já estavam claramente estabelecidas as bases de capitalização crescente do sistema de saúde, com o início do processo de estruturação do segmento de planos e seguros de saúde, no campo das vacinas o Estado consolida o PNI e lança o PASNI. Dessa forma, propunha-se a garantir a auto-suficiên- cia do país na oferta das vacinas consideradas essenciais.

Ao contrário da indústria de medicamentos, que desde a década de 50 iniciara um forte processo de internacionalização da indústria no país, no segmento de vacinas a década de 80 vê o último produtor privado de capital estrangeiro interromper sua produção. Portanto, desse ponto de vista, este segmento pode ser considerado como de inserção tardia na dinâmica mercantil do CMI brasileiro.

Como determinantes fundamentais dessa especificidade na dinâmica do mercado de vacinas no país, podem ser citados:

- A especificidade do objeto vacina e sua força simbólica no conjunto de instrumentos de intervenção no campo da saúde. Seu capital simbólico está marcadamente vinculado à idéia da vacina como um bem público, como um instrumento do Estado no controle de determinadas situações sanitárias;

- O conjunto de recursos financeiros mobilizados no setor, dado pelo baixo valor agregado dos produtos disponíveis até então, era ainda restrito em relação ao conjunto do mercado de medicamentos, ou seja, um segmento de baixa expressão econômica;

- A até então baixa dinâmica de inovações nesse segmento, só quebrada a partir de 1986 com o licenciamento para uso da vacina contra a hepatite B;

- A política de seletividade restritiva adotada nas décadas de 80 e 90 pelo Estado na definição do conjunto de vacinas disponibilizadas no PNI, não incorporando ao calendário obrigatório os novos produtos;

- O desinteresse da indústria farmacêutica e dos grandes produtores por esse segmento, dada sua baixa dinâmica e insuficiente retorno financeiro.

Este processo de inserção tardia na dinâmica mercantilista setorial determinaria alguma singularidade em seu processo de estruturação? Alguns fatores podem ter contribuído para conceder uma certa especificidade no desenvolvimento desse segmento. Um deles foi a opção do país por manter e modernizar a indústria estatal, criando uma capacidade instalada significativa para a produção de produtos tradicionais que garantissem a maior parte da oferta dos produtos utilizados pelo PNI. Ao iniciar este processo de mudança (da oferta artesanal/ marginal para o desenho de um segmento estruturado) já encontra um segmento privado de oferta de serviços médico-hospitalares, desenvolvendo e aperfeiçoando um conjunto de práticas e lógicas de organização do cuidado assistencial. Seu ritmo de expansão estaria limitado 
pelo alto preço desses novos produtos e pelo fato de o Estado ainda prover as vacinas mais importantes. Por outro lado, ele cresce em um momento de crise da qualidade dos serviços públicos, mas onde a oferta estatal de vacinas ainda se mantêm como espaço respeitado criando uma espécie de contraponto à hegemonia crescente do espaço privado no setor saúde.

No caso do Brasil, a erradicação da varíola, a drástica redução da poliomielite e sarampo, por meio das campanhas de controle de âmbito nacional, e o enfrentamento da epidemia de meningite nos anos 70 contribuíram para criar uma "cultura" positiva, uma imagem moderna e "protetora" para a vacina como estratégia médica de atenção. Esta dinâmica, que retoma a tradição Pasteuriana em novas bases, onde o desenvolvimento da ciência ocupa um papel central, criará as condições necessárias para o desenvolvimento de um subsetor específico, composto por organizações e práticas até então incipientes: o da comercialização privada de vacinas por intermédio da estruturação de uma rede de clínicas de vacinação e de consultórios médicos, hospitais e empresas, como espaço complementar e alternativo da rede pública. Este novo segmento se insere sem conflitos no interior do CMI.

De fato, ao oferecer produtos tecnologicamente mais modernos, não disponíveis no PNI, ele vem suprir uma lacuna articulando-se funcionalmente e politicamente à medicina privada e às praticas empresariais no campo da prevenção e da promoção.

Entretanto, a caracterização deste mercado, em contraponto ao de especialidades farmacêuticas, deve considerar outros aspectos. No caso dos medicamentos, seu consumo se banalizou enquanto recurso terapêutico, estimulado em grande parte pelas estratégias comerciais e pela incorporação cultural do autoconsumo enquanto estratégia corriqueira de recuperação da saúde. Já no caso das vacinas, estas ainda são vistas com reserva, como um recurso mais nobre, manipulável apenas no campo restrito do saber médico e das práticas institucionais. Seu consumo ainda depende fortemente da intermediação do profissional médico e do conjunto de instituições públicas envolvidas no desenvolvimento das políticas preventivas no campo da saúde. Estas características colocam limites ao processo de ampliação do consumo e estabelecem processos específicos às estratégias de comercialização.

\section{Estruturação e consolidação do segmento privado}

No Brasil a produção e a oferta de vacinas sempre estiveram sob forte hegemonia estatal. A própria história do desenvolvimento da saúde pública brasileira se confunde com a estruturação de instituições produtoras de biológicos. Entretanto, a participação de empresas privadas neste campo, apesar de historicamente minoritária, destacou-se em situações específicas. De fato, o desenvolvimento do segmento de produção privada de produtos biológicos deuse a partir do Estado (Fernandes, 1999; Ribeiro, 2001).

Estas relações, de forte conteúdo estruturante, têm-se mantido presentes em toda a trajetória das organizações de desenvolvimento e produção de imunobiológicos. "Durante as décadas de 1920 e 1930, senão até hoje, a trajetória dos Institutos Butantan e Oswaldo Cruz seria, em larga medida, condicionada pelo campo de tensão gerado por essa contradição entre o público e o privado na produção e distribuição de terapêuticos..." (Benchimol \& Teixeira, 1993:181).

No campo das vacinas, mais que uma contradição, estabelece-se uma organicidade entre produção e consumo nos espaços público e privado. O segmento privado de oferta de vacinas é gestado, estimulado e, em seu início, mantido pelo próprio Estado.

As primeiras clínicas de imunização privadas do país se estabelecem no início dos anos 70, antes mesmo da estruturação do PNI. Seus principais exemplos são a Climuno - Clínica de Vacinação fundada por três sanitaristas, entre eles Nelson Moraes no Rio de Janeiro, e a Clínica Especializada em Doenças Infecciosas e Parasitárias e Imunizações (CEDIPI) por Gabriel Oselka e outros médicos em 1972, em São Paulo.

O conjunto de fatores envolvidos na estruturação da CEDIPI é um exemplo do modo como o segmento privado de oferta se organiza no Brasil. Segundo Gabriel Oselka (proprietário da clínica CEDIPI, em entrevista realizada em 22 de outubro de 2001), em São Paulo, no início dos anos 70 um grupo de médicos do Hospital dos Servidores Públicos exercia suas atividades em um dos primeiros postos de vacinação organizado em hospital público do país, vinculado ao Serviço de Doenças Infecciosas e Parasitárias, chefiado à época pelo Dr. Vicente Amato. Espaço diferenciado de prática clínica onde os médicos, residentes e internos participavam em conjunto das atividades, era considerado à época um posto de saúde padrão. O grande interesse despertado pelas vacinas como instrumento de prevenção, aliado à crescente credi- 
bilidade conquistada pelas políticas públicas nesse campo, aumentava o interesse de profissionais médicos em estabelecer um espaço diferenciado e especializado, onde pudessem prestar seus serviços. Esta opção respondia, possivelmente, a demandas crescentes da sociedade por espaços diferenciados daqueles disponibilizados pelo Estado na oferta de vacinas.

Surge então a idéia de se aliar a prática liberal de consultório à oferta de vacinas, em uma visão de diferenciação dos serviços oferecidos. No caso do CEDIPI, o atendimento desde o início de sua fundação era realizado apenas por médicos: um claro movimento de diferenciação, dado que o espaço das práticas de imunização era fortemente dominado por profissionais de enfermagem.

A CEDIPI, assim estruturada, começou por oferecer serviços de imunização utilizando as seguintes vacinas: DPT, sarampo, Sabin e BCG oral. A clínica era credenciada a vacinar de modo integrado ao sistema público. A cobrança pelos serviços limitava-se aos honorários médicos, decorrentes da consulta médica prévia ao ato de imunização (G. Oselka, entrevista). Ou seja, a clínica atuava na prática como um posto de saúde especificamente voltado para a aplicação das vacinas constantes do calendário do PNI. Obviamente, visava a um público diferenciado capaz de pagar pelo ato médico que antecedia a vacinação. Mas, desde o início, a clínica ofertava um produto que o PNI só iria incorporar na década de 90: a vacina tríplice viral que tem sua importação iniciada em 1973 e só seria gradualmente incorporada ao PNI a partir de 1992.

A possibilidade de conjugar oferta privada utilizando-se de vacinas fornecidas pelo Estado só foi possível por meio da existência de uma regulamentação específica. Em 1977, a Resolução 42, do então Secretário de Saúde do Estado de São Paulo, Walter Leser, estabelecia diretrizes para o credenciamento de postos de vacinação privados na área do território paulista a fim de atuarem na execução do PNI do MS. Um conjunto de pré-requisitos eram exigidos para o credenciamento e, em seu artigo terceiro, estabelecia que os mesmos, “... serão abastecidos gratuitamente com vacinas previstas como obrigatórias no PNI. Poderão, se assim o desejarem, receber honorários pelo exame médico realizado antes da vacinação" (SES-SP, 1977).

Em 1978, o então Secretário de Saúde Pública do Estado de Sergipe solicita orientação ao Ministério da Saúde (MS) sobre como proceder em relação às clínicas particulares onde eram desenvolvidas atividades de vacinação. Ele refere-se especificamente a dois aspectos: ao fornecimento de vacinas pela Secretaria de Saúde a essas clínicas; e de que modo elas poderiam cobrar pelo serviço realizado (MS, 1978). Em resposta, a consultoria jurídica do MS, segundo parecer de número 4-108/1978 e baseando-se no Decreto 78.231 de 1976 que regulamentou a Lei 6.259 de 1975, esclarecia que o artigo 33 itens VI e VII do referido decreto, definia como funções das Secretarias de Saúde: VI - "promover a criação de postos de vacinação em todos os serviços de saúde de natureza pública e particular"; VII - "credenciar médicos, como agentes, para a execução de vacinações” (MS, 1978).

Por outro lado, o artigo 40 do mesmo decreto afirmava a gratuidade das vacinas obrigatórias ao frisar que "as vacinas obrigatórias e seus respectivos atestados serão gratuitos inclusive quando executados por profissionais em suas clínicas ou consultórios, ou por estabelecimentos privados de prestação de serviços de saúde" (MS, 1978).

O parecer do MS concluía com as seguintes recomendações: "as vacinas obrigatórias distribuídas pelas Secretarias de Saúde às entidades privadas e aos agentes de vacinação credenciados, bem como o ato de emissão do atestado de vacinação lançado na caderneta nacional de imunizações padronizada pelo MS, serão gratuitos. Não existe proibição legal expressa à cobrança pelas pessoas credenciadas dos serviços relacionados à aplicação das vacinas obrigatórias..." (MS,1978).

Fica evidente, desde o nascedouro, as íntimas relações estabelecidas entre o desenvolvimento do PNI e a criação de um mercado nos moldes capitalistas para a área da oferta de serviços de imunização. A partir do conhecimento acumulado na organização de um serviço público diferenciado de imunização, o grupo de médicos em São Paulo estabelece espaço privado de oferta dos mesmos serviços. Essa relação apóia-se inclusive na oferta dos imunobiológicos a partir do próprio Estado. Ou seja, o fenômeno que se havia processado no espaço da produção repete-se no da oferta: Ribeiro (2001), com base no trabalho original de Benchimol \& Teixeira (1993), reflete sobre as relações entre os laboratórios privados e os institutos públicos de pesquisa e produção, tratando de uma "mercantilização da ciência”, em que “...a difusão do consumo de produtos elaborados nos laboratórios dos institutos públicos tornou a atividade produtiva lucrativa, e os cientistas das instituições públicas, que detinham o saber fazer, passaram a ter interesse no estabelecimento de empresas ou no trabalho realizado na iniciativa privada. $O$ know how adquirido pelos profissionais em instituições estatais seria posto a serviço de interesses mercantis" (Ribeiro, 2001:619). 
A estruturação em âmbito nacional de um programa voltado especificamente ao combate às doenças infecciosas por meio da imunização expande um conjunto de saberes, tecnologias e práticas institucionais, dentro do espaço público. Médicos e outros profissionais que exercem sua prática nos serviços públicos, com base em conhecimento e práticas ali adquiridas e acumuladas, e de avaliação das possibilidades comerciais vislumbradas por um novo negócio, sentem-se estimulados a estabelecer um serviço privado. No início, o próprio Estado era o fornecedor do principal insumo necessário: a vacina.

Processo semelhante ocorreu no espaço do desenvolvimento e da produção a partir da década de 30, mas que apenas nos anos 70 veria sua contraface no espaço da comercialização privada, sob a forma da organização de empresas especializadas na oferta de serviços de imunização. De início, o nascente segmento privado de oferta trabalhava praticamente com os mesmos produtos do PNI, com exceções muito específicas. Este fato estava determinado pelas próprias limitações da indústria e pela inexistência de novos produtos no mercado. Clínicas e consultórios funcionavam como complemento à rede pública. Entretanto, a existência de cobrança pelo ato médico precedente à vacinação obviamente limitava o acesso a esses espaços a extratos populacionais em condições de pagar. De outro lado, o fornecimento das vacinas pelo Estado, na prática, funcionava como subsídio ao desenvolvimento do mercado privado nesta área.

A ciência, ao desenvolver e colocar no mercado um produto que o revolucionaria e lhe traria nova dinâmica, daria novo impulso a este nascente e ainda tímido segmento do mercado. Teríamos então finalmente, a transformação da vacina em uma mercadoria "submetida às regras de produção, financiamento e distribuição de tipo capitalista" (Braga \& Silva, 2001:21).

O segmento que se estrutura a partir de então vai envolver empresas produtoras, importadores, distribuidores, médicos especialistas (principalmente pediatras, clínicos gerais, infectologistas, ginecologistas e obstetras, e gerontologistas), entidades médicas, escolas, empresas e consumidores individuais. Em uma visão abrangente, esta atividade historicamente entendida como eminentemente pública (reforçada pela mística da Fundação Oswaldo Cruz e do Instituto Butantan) foi gradualmente construindo outra face, contraponto à que lhe deu origem. Voltada basicamente para a população de maior poder aquisitivo e que já utiliza o sistema privado de assistência médica, é desen- volvida por clínicas especializadas e consultórios de especialistas onde são oferecidos horários flexíveis de atendimento, conforto e visual moderno, além de atendimento em domicílio ou no local de trabalho. Lá, podem ser encontrados não só produtos não disponíveis nos centros de saúde, mas também as vacinas tradicionais, criando um espaço de "competição" com o setor público.

Os extratos de maior poder aquisitivo, empresas e escolas são seus principais clientes. Todos buscam novas opções de consumo neste campo, em parte estimulados pela mídia. Matérias sobre saúde, práticas saudáveis de vida e prevenção de doenças freqüentam com assiduidade as revistas semanais, as publicações dirigidas ao público feminino e os principais jornais. No caso específico das vacinas, o público alvo é composto principalmente pelos pediatras, clínicos, gerontologistas e outros especialistas. A estes a indústria dedica esforços e adota estratégias de marketing semelhantes às utilizadas pela indústria de medicamentos. De fato, as tendências internacionais parecem aproximar as estratégias de comercialização dessas duas indústrias (Temporão, 2002). Por outro lado, grandes e médias empresas passam a oferecer a seus funcionários e familiares o acesso a algumas dessas novas vacinas dentro de uma concepção de saúde no trabalho (prevenção), motivadas principalmente pela possibilidade de diminuir o tempo de afastamento do trabalho em caso de doença. Este conjunto de fatores vai estabelecer uma nova dinâmica para o mercado, ampliando os interesses dos produtores internacionais.

O quadro percebido no início dos anos 90 já era bem distinto. A introdução no mercado da vacina recombinante contra a hepatite $\mathrm{B}$ iria causar uma radical expansão deste segmento. Como o PNI não incorporou esta nova vacina ao seu elenco de recursos, teve início a proliferação de estratégias privadas de oferta, que tem em consultórios médicos e clínicas especializadas as principais formas de organização. $\mathrm{O}$ surgimento de outras vacinas modernas, como a vacina contra Haemophilus B, influenza, hepatite A e outras, ampliaria ao longo da década de 90, ainda mais este mercado.

Até o surgimento da vacina contra hepatite $\mathrm{B}$, os produtos ofertados pelo PNI e pelas poucas clínicas e consultórios eram praticamente os mesmos. O mercado era restrito, voltado para segmentos específicos da sociedade. Segundo G. Oselka (entrevista), “o PNI não tinha a credibilidade que tem hoje. Até a metade dos anos 80 nossa clínica vacinava mais do que hoje e praticamente com as mesmas vacinas que o 
PNI oferecia". As relações estabelecidas entre o PNI e esse nascente segmento privado, desde o início, foram marcadas pela complementaridade. De fato, nunca teria existido um padrão de competição entre o PNI e o segmento privado, mas sim um processo de interpenetração de espaços, onde o setor privado se estabelece em nichos definidos pela ausência de oferta ou oferta restrita por parte do Estado.

Entrevista realizada com proprietária de clínica privada evidencia este aspecto: "Vejo o PNI como um fator positivo que ajuda a abrir mercado. O PNI ampliou a consciência da população em relação à imagem da vacina. Isto levou inclusive a um aumento da demanda por vacinas de adultos. Por exemplo, se o PNI introduz uma nova vacina, o mercado se abre para novos produtos como vacinas combinadas" (Regina Tavares, proprietária da clínica PREVCLIN, em entrevista realizada em 21 de setembro de 2001).

Trata-se da construção de um processo de deslocamento e ampliação direcionado não apenas por demandas de um mercado que se sofistica e amplia, mas principalmente, pelo desenvolvimento e lançamento de novos produtos, em que nichos de mercado se superpõem, substituem e se complementam sempre que necessário. Exemplo disso é quando o PNI incorpora com restrições uma nova vacina como, por exemplo, a oferta de vacina contra hepatite $\mathrm{B}$ apenas a menores de vinte anos ou de gripe a maiores de 60.

O outro extremo é quando o PNI incorpora ao calendário de vacinação um produto para cobertura universal da população. Nesse caso o volume de recursos vinculados à comercialização privada desses produtos se reduz substancialmente. A pesquisa de campo realizada, demonstra que a partir de 1998 a vacina Hib (que havia sido um dos "carros-chefes" do processo de crescimento do mercado), ao ser incorporada universalmente ao PNI, levou à redução dos gastos com sua importação pelo segmento privado em $80 \%$ (Temporão, 2002).

O processo de estruturação desse segmento apresenta características singulares. Uma das clínicas entrevistadas surge e se estabelece em torno de um único produto. A Clínica de Imunizações Vaccini, criada em 1993, uma das primeiras do Rio de Janeiro, surgiu da idéia de constituir a empresa a partir do trabalho da proprietária como médica especialista em saúde escolar. Como o PNI não oferecia a vacina contra Haemophillus tipo B, utilizada em crianças, esse foi o estímulo para realizar uma campanha voltada no primeiro momento para as creches privadas. A partir daí, a empresa se estruturou e ampliou suas atividades (Izabella Benevides, proprietária da clínica VACCINI, em entrevista realizada em 18 de setembro de 2001).

Esta dinâmica passa a constituir subsegmentos dentro do mercado. Um é constituído por empresas que tradicionalmente implementam políticas estabelecidas pelos departamentos de saúde ocupacional. Estas passam a ser um dos alvos do segmento privado, principalmente para as vacinas contra influenza, tétano e hepatite B. Da mesma forma, os planos de autogestão, cada mais vez mais abertos a estas práticas, começam a subsidiar a vacinação privada de seus associados.

A importância dos consultórios como espaço de consumo é destacada por Oselka (entrevista). Hoje a principal oferta no segmento não seria de clínicas formalmente estruturadas, mas de médicos especialistas que imunizam em seus consultórios. Para o entrevistado é a forma mais comum de oferta neste segmento. Aponta ainda que, dadas às suas dimensões e características, esta prática coloca dificuldades aos órgãos de saúde pública para fiscalizar e controlar (Oselka, entrevista).

As relações entre os vários atores no interior do segmento estão determinadas pelas relações econômicas. As distribuidoras, por exemplo, comercializam os produtos adquiridos diretamente dos fabricantes e desenvolvem atividades de promoção sempre em conjunto com os laboratórios produtores. Segundo entrevista realizada com uma das maiores distribuidoras de vacinas do país, a Express, na prática elas competiriam com os produtores no processo de vendas para clínicas, consultórios e empresas; entretanto podem vender produtos de vários fabricantes, têm maior agilidade, pois são voltadas especificamente para vendas, além de poder vender produtos em pequenas quantidades (Waldir Grasso, diretor da distribuidora de vacinas Express, em entrevista realizada em 27 de novembro de 2001).

O aumento da competição e os crescentes interesses econômicos trariam consigo alguns problemas. Um deles decorreria da falta de experiência comercial da maioria dos profissionais de saúde que se envolvem com este mercado, levando à aproximação destes profissionais, principalmente dos proprietários das pequenas clínicas, com empresários sem nenhuma inserção orgânica na saúde ou mesmo sem qualquer projeto mais conseqüente no campo da saúde. Segundo um dos entrevistados, opera no mercado um "limitador de negócios", ou seja, quanto mais se respeitam os limites éticos entre a demanda e a exigência legal da prescrição médica, mais reduzidas as possibilidades de o negócio crescer (Tavares, entrevista). 
De toda forma, as campanhas de vacinação em massa do governo parecem ampliar o mercado para todos. "Com o início das campanhas, o aumento da procura à clínica é imediato. Se durante a campanha os serviços públicos entram em greve, como ocorreu recentemente com a rubéola, nossa demanda também aumenta" (Nelson Moraes Filho, proprietário da clínica CLIMUNO, em entrevista realizada em 6 de dezembro de 2001).

A base sobre a qual se apóiam as forças que direcionam o segmento privado está determinada, em grande parte, pelas estratégias comerciais dos grandes fabricantes.

\section{O segmento privado de vacinas: dimensões, principais produtos e fabricantes}

As informações referentes às vendas de vacinas no mercado brasileiro, assim como da participação das principais empresas e produtos, são mantidas sob rigoroso sigilo pelas empresas. De fato, este segmento do mercado é totalmente desconhecido do setor público responsável em última análise pelo seu controle, nos termos da legislação em vigor. Durante o trabalho de levantamento das informações sobre o setor e ao longo das entrevistas, os comentários dos formuladores de políticas, dirigentes do MS, das empresas produtoras e especialistas, variaram entre "minimizar sua importância" até considerá-lo como "desprezível dentro do contexto setorial”. No entanto, a realidade mostra-se bastante distinta.

A tentativa de delimitar o universo de pontos de venda de vacinas, incluindo clínicas e consultórios, foi de difícil realização. Esforços realizados junto à Sociedade de Pediatria do Estado do Rio de Janeiro (SOPERJ), no sentido de obter informações sobre o número de pediatras que desenvolvem serviços de vacinação em seus consultórios, foram infrutíferos. Esta entidade afirma desconhecer qualquer estudo, ou mesmo estimativa neste sentido (SOPERJ, entrevista realizada com sua diretoria, em setembro de 2001). Esforço semelhante realizado junto à Secretaria Municipal de Saúde do Rio de Janeiro (SMS-RJ), no sentido de obter uma estimativa do universo desses serviços instalados na cidade, também não obteve sucesso. Embora, por determinação legal, todas as clínicas e consultórios devam estar cadastradas junto às secretarias de saúde de cada município, na prática esses cadastros não se encontravam à época, disponíveis para consulta (Maria Cristina F. Lemos, coordenadora de imunizações da SMS-RJ, realizada em 25 de outubro de 2001).

A caracterização desse universo, ainda que de modo aproximado, só foi possível por meio das entrevistas realizadas com o principal distribuidor de vacinas do país e com um dos maiores fabricantes mundiais.

A entrevista realizada com aquela que é considerada a maior distribuidora de vacinas do país, a Express, detentora de $60 \%$ do mercado de distribuição, permitiu uma primeira aproximação a esse universo. Consulta ao seu cadastro de pontos de venda permitiu sua delimitação aproximada. A empresa possui cerca de 3.800 pontos de venda ativos, assim distribuídos: 380 clínicas de vacinação, 1.900 consultórios médicos, 380 hospitais e 1.140 empresas (W. Grasso, entrevista).

A projeção desses dados para o universo de unidades envolvidas no mercado leva à estimativa de um total de 600 clínicas, 3 mil consultórios, 600 hospitais e cerca de 2 mil empresas que realizam rotineiramente atividades de imunização em seus funcionários. Ou seja, cerca de 6.200 pontos de vendas.

Entrevista realizada com o gerente de produtos de grande produtora multinacional (Amauri Gomes, da empresa Alfa, entrevista realizada em 18 de março de 2002) sediada no país permitiu obter números que se aproximam muito dessa estimativa. Segundo essa fonte, existem hoje cerca de 450 clínicas de imunização no Brasil, cerca de 3.500 pediatras que vacinam em seus consultórios, e entre 2 mil a 3 mil empresas que realizam com regularidade atividades de vacinação.

Os dados obtidos apontam para uma divisão do mercado em que os fabricantes detêm cerca de $60 \%$ das vendas e as distribuidoras cerca de $40 \%$. O mercado está basicamente concentrado em São Paulo, para onde se destinam cerca de $50 \%$ das vendas. Seguem-se os estados da Região Sul e Sudeste e, com uma parcela reduzida do mercado, as regiões Centro-Oeste, Norte e Nordeste (W. Grasso, entrevista).

O levantamento, sistematização, tabulação e análise dos dados obtidos na pesquisa de campo, em relação à caracterização do segmento privado, permitiram obter informações que delineiam com clareza seu peso e dinâmica dentro do setor saúde.

A Tabela 1 mostra a evolução das importações do segmento privado para o período 1997 2001. O total de importações atingiu cerca de 20 milhões de dólares em 2001 . Há uma redução dos gastos com importações de cerca de $18 \%$ no período analisado, além de importante mudança no perfil dos produtos importados. Enquan- 
Evolução das importações* do segmento privado do mercado de vacinas. Brasil, 1997-2001.

\begin{tabular}{|c|c|c|c|c|c|c|c|c|c|c|}
\hline Vacinas & 1997 & $\%$ & 1998 & $\%$ & 1999 & $\%$ & 2000 & $\%$ & 2001 & $\%$ \\
\hline Poliomielite & 19.306 & 0,08 & 55.606 & 0,23 & 64.222 & 0,29 & 49.976 & 0,28 & 203.830 & 1,05 \\
\hline Sarampo & 105.295 & 0,45 & 10.861 & 0,04 & 34.241 & 0,16 & 15.133 & 0,09 & 11.215 & 0,06 \\
\hline Tríplice bacteriana/DTP & 230.350 & 0,97 & 6.335 & 0,03 & 24.892 & 0,11 & 32.940 & 0,19 & 23.882 & 0,12 \\
\hline Dupla adulto & 17.824 & 0,08 & 17.184 & 0,07 & 31.222 & 0,14 & 36.073 & 0,21 & 87.482 & 0,45 \\
\hline Tétano & 54.475 & 0,23 & 32.440 & 0,13 & 55.888 & 0,25 & 55.587 & 0,32 & 70.730 & 0,36 \\
\hline Rubéola & 1.293 & 0,01 & 8.336 & 0,03 & 9.166 & 0,04 & 2.474 & 0,01 & 9.210 & 0,05 \\
\hline Caxumba & 3.089 & 0,01 & & 0,00 & 6.252 & 0,03 & 2.287 & 0,01 & 1.089 & 0,01 \\
\hline Raiva & 10.450 & 0,04 & 20.724 & 0,09 & 21.365 & 0,10 & 30.905 & 0,18 & 137.133 & 0,70 \\
\hline Meningite $A / C$ & 168.224 & 0,71 & 136.485 & 0,56 & 260.055 & 1,18 & 256.013 & 1,46 & 189.567 & 0,97 \\
\hline Meningite $B / C$ & 99.730 & 0,42 & 353.240 & 1,46 & 219.581 & 1,00 & 499.033 & 2,84 & 253.565 & 1,30 \\
\hline Pneumococo & 470.825 & 1,99 & 1.083 .067 & 4,47 & 877.862 & 3,98 & 195.783 & 1,11 & 357.274 & 1,83 \\
\hline Tríplice viral & 924.391 & 3,91 & & 0,00 & 223.471 & 1,01 & 239.021 & 1,36 & 85.709 & 0,44 \\
\hline Hepatite B & 5.188 .978 & 21,94 & 4.040 .400 & 16,69 & 983.089 & 4,46 & 623.120 & 3,55 & 457.046 & 2,35 \\
\hline Haemophillus influenzae B & 5.707 .758 & 24,14 & 3.960 .585 & 16,36 & 3.987 .961 & 18,10 & 733.928 & 4,18 & 449.490 & 2,31 \\
\hline Influenza & 2.473 .736 & 10,46 & 9.634 .086 & 39,80 & 7.454 .822 & 33,83 & 7.021 .895 & 39,96 & 9.915 .453 & 50,93 \\
\hline Hepatite A & 4.086 .791 & 17,28 & 1.391 .267 & 5,75 & 1.628 .474 & 7,39 & 2.292 .889 & 13,05 & 1.296 .066 & 6,66 \\
\hline Hepatite A/B & & 0,00 & 1.267 .388 & 5,24 & 1.872 .282 & 8,50 & 2.029 .394 & 11,55 & 893.537 & 4,59 \\
\hline $\begin{array}{l}\text { Tríplice bacteriana } \\
\text { acelular/DTaP }\end{array}$ & 15.073 & 0,06 & & 0,00 & 1.056 .773 & 4,80 & 742.045 & 4,22 & 648.184 & 3,33 \\
\hline $\mathrm{DTP}+\mathrm{Hib}$ & 3.981 .180 & 16,84 & 1.396 .574 & 5,77 & 811.413 & 3,68 & 116.580 & 0,66 & 70.707 & 0,36 \\
\hline DTP + pólio inativada & 80.286 & 0,34 & 20.709 & 0,09 & & 0,00 & & 0,00 & & 0,00 \\
\hline Pneumococo conjugada & & 0,00 & & 0,00 & & 0,00 & 85.755 & 0,49 & 893.037 & 4,59 \\
\hline Varicela & & 0,00 & 628.895 & 2,60 & 2.153 .278 & 9,77 & 2.111 .700 & 12,02 & 2.021 .210 & 10,38 \\
\hline DTP + Hepatite B & & 0,00 & 144.957 & 0,60 & 49.272 & 0,22 & & 0,00 & 1.799 & 0,01 \\
\hline $\begin{array}{l}\text { DTP acelular }+ \\
\text { pólio inativada }+ \text { Hib }\end{array}$ & & 0,00 & & 0,00 & 200.506 & 0,91 & 401.005 & 2,28 & 1.387 .638 & 7,13 \\
\hline Outras & 7.384 & 0,03 & & 0,00 & 9.370 & 0,04 & & 0,00 & 5.359 & 0,03 \\
\hline Total geral & 23.646 .438 & 100,00 & 24.209 .139 & 100,00 & 22.035 .457 & 100,00 & 17.573 .536 & 100,00 & 19.470 .212 & 100,00 \\
\hline
\end{tabular}

* em US\$.

Fonte: Divisão de Estatística do Comércio Exterior, Ministério da Fazenda.

to em 1997 as vacinas hepatite B e Haemophillus influenzae tipo b (Hib) respondiam por $46 \%$ do total de importações, em 2001 foram responsáveis por apenas $4,6 \%$.

Por outro, lado observa-se um crescimento importante do mercado para a vacina Influenza, que em 2001 foi responsável por metade das importações para este segmento em valores, alcançando cerca de 10 milhões de dólares. Um outro conjunto mais restrito de vacinas modernas responde por porcentual também significativo, como hepatite A, hepatite A/B, varicela, pneumococo conjugada e as novas vacinas combinadas.

Como fica evidente, as importações realizadas por este segmento destinam-se principalmente à oferta de produtos modernos, embora mantenha-se um fluxo de importações para as vacinas tradicionais voltado para nichos de mercado em que a demanda por produtos tradicionais ainda persiste.

Pode ser observado uma forte tendência de redução da participação dos produtos tradicionais no conjunto das importações. Percebe-se que o principal fator responsável pela redução dos valores comprometidos com importações foi a queda da participação das vacinas tradicionais no conjunto de gastos. Ë importante destacar que as importações das vacinas modernas manteve-se em torno de 20 milhões de dólares no período, mesmo se considerada a forte desvalorização da moeda brasileira ocorrida em 1999.

A dinâmica observada está intimamente relacionada às transformações em andamento no mercado como um todo, principalmente o desenvolvimento mais recente do PNI. A Tabela 2 ilustra esta análise. 
Comparativo do quantitativo de doses utilizadas nos segmentos público e privado para algumas vacinas. Brasil, 1997-2001.

\begin{tabular}{|c|c|c|c|c|c|c|c|c|c|c|}
\hline \multirow[t]{2}{*}{ Vacinas } & \multicolumn{2}{|c|}{1997} & \multicolumn{2}{|c|}{1998} & \multicolumn{2}{|c|}{1999} & \multicolumn{2}{|c|}{2000} & \multicolumn{2}{|c|}{20011} \\
\hline & PNI & Privado & PNI & Privado & PNI & Privado & PNI & Privado & PNI & Privado \\
\hline Hepatite B & 16.000 .000 & 1.035 .085 & 24.000 .000 & 858.491 & 18.621 .810 & 216.092 & 11.550 .000 & 148.805 & ND & 142.820 \\
\hline $\mathrm{Hib}$ & 9.000 & 515.034 & 2.022 .000 & 508.232 & 16.000 .000 & 616.873 & 14.577 .000 & 152.987 & ND & 97.286 \\
\hline Hepatite A & 0 & 364.750 & & 142.518 & 12.000 & 194.216 & 4.000 & 280.846 & ND & 205.834 \\
\hline Influenza & 0 & 680.364 & 4.270 .000 & 2.518 .686 & 4.730 .000 & 2.719 .114 & 14.000 .000 & 2.558 .252 & ND & 2.578 .252 \\
\hline Hepatite A/B & 0 & 0 & 0 & 95.000 & 0 & 178.400 & 0 & 246.590 & ND & 114.530 \\
\hline Varicela & 0 & 0 & 0 & 4.900 & 14.000 & 95.165 & 6.450 & 170.010 & ND & 158.117 \\
\hline Tríplice viral & 24.250 .000 & 207.740 & 15.725 .000 & 0 & 15.933 .500 & 95.496 & 18.340 .000 & 111.973 & ND & 33.390 \\
\hline
\end{tabular}

1 Dados não disponíveis para o PNI.

$\mathrm{PNI}=$ Programa Nacional de Imunização; ND = não disponível.

Fonte: Divisão de Estatística do Comércio Exterior e PNI.

A ampliação do processo de universalização da oferta de vacinas pelo PNI (como hepatite $\mathrm{B}$, Hib e tríplice viral) leva à grande redução no volume destes produtos comercializados no segmento privado. À medida que sua incorporação ao calendário oficial do PNI progride, observa-se uma queda significativa do volume de doses importadas para o segmento privado. Mantém-se entretanto, um espaço residual voltado para segmentos e demandas específicos da população. No caso da vacina contra influenza, o segmento privado mantém praticamente estável seu volume de negócios, apesar de o PNI tê-la incorporado ao calendário oficial. Isso ocorre pelo fato de o PNI disponibilizar este produto apenas aos maiores de 60 anos de idade, fazendo com que o segmento privado mantenha um espaço específico no mercado, voltado para atender às demais faixas etárias, além dos maiores de 60 anos que por variados motivos o utilizam. Já as vacinas contra hepatite A, hepatite A/B e varicela, que ainda se encontram na fase de lançamento no ciclo de vida desses produtos, ampliam no mesmo período, sua presença no segmento privado.

As importações de vacinas para o segmento privado do mercado no Brasil são oriundas predominantemente de duas das principais empresas do setor. A GlaxoSmithKline e a Aventis Pasteur, em conjunto, responderam em 2001, por cerca de $80 \%$ das importações. Como pode ser visto na Tabela 3 e na Figura 1, outros três fabricantes foram responsáveis, naquele ano, pela maior parte do fornecimento restante de vacinas para este segmento. Esta participação se manteve sem grandes oscilações no período analisado, com exceção da entrada em 2001 da
Novartis com cerca de oito por cento das importações, e da Wyeth, que apresentou um crescimento de sua participação de 2,93\% em 1997, para $4,59 \%$ em 2001. A Merck perde mercado no período em tela com uma redução de cerca de $60 \%$ no volume de produtos importados pelo segmento privado do mercado brasileiro.

A participação dos produtores na importação das principais vacinas pode ser apreciada na Tabela 4.

A Aventis Pasteur detém a hegemonia nas importações das vacinas influenza, varicela, hepatite A, tríplice bacteriana e Hib, que responderam por cerca de $90 \%$ do total de produtos fornecidos por essa empresa. A GlaxoSmithKline tem forte presença também em influenza e varicela, com destaques para as vacinas hepatite A/ B e pentavalente combinada. As demais apresentam portfolio restrito com destaque para a Wyeth que vem ampliando sua participação no mercado, com a nova vacina conjugada contra pneumococo. Alguns produtos tradicionais são fornecidos pela Aventis (poliomielite, meningite a/c e dupla adulto), GlaxoSmithKline (poliomielite) e Novartis (poliomielite e dupla adulto).

Entretanto, o volume de recursos envolvidos no segmento privado apresentado até aqui refere-se apenas àqueles gastos com as importações, acrescidos dos impostos. O passo seguinte, ou seja, sua comercialização no mercado, movimenta volume de recursos muito mais significativo. Para melhor aproximação dessa realidade, procedeu-se ao levantamento dos preços de venda ao consumidor praticados em nove das maiores clínicas privadas da cidade de São Paulo, estado que responde por cerca $50 \%$ do mercado nacional deste segmento. $\mathrm{O}$ 
Tabela 3

Evolução da participação dos principais produtores nas importações* do segmento privado do mercado de vacinas. Brasil, 1997-2001.

\begin{tabular}{|c|c|c|c|c|c|c|c|c|c|c|}
\hline \multirow[t]{2}{*}{ Fabricantes } & \multicolumn{2}{|c|}{1997} & \multicolumn{2}{|c|}{1998} & \multicolumn{2}{|c|}{1999} & \multicolumn{2}{|c|}{2000} & \multicolumn{2}{|c|}{2001} \\
\hline & Total & $\%$ & Total & $\%$ & Total & $\%$ & Total & $\%$ & Total & $\%$ \\
\hline Aventis Pasteur & 12.607 .643 & 53,32 & 11.434 .655 & 47,23 & 12.321 .350 & 55,92 & 7.914 .889 & 45,04 & 9.452 .717 & 48,55 \\
\hline Smithkline Beecham & 7.400 .854 & 31,30 & 7.903 .306 & 32,65 & 4.572 .118 & 20,75 & 6.982 .447 & 39,73 & 5.958 .999 & 30,61 \\
\hline Novartis & & & & & & & & & 1.614 .052 & 8,29 \\
\hline Merck Sharp \& Dohme & 2.706 .754 & 11,45 & 3.714 .768 & 15,34 & 3.948 .405 & 17,92 & 1.559 .555 & 8,87 & 1.083 .531 & 5,57 \\
\hline Laboratórios Wyeth & 691.791 & 2,93 & 498.162 & 2,06 & 763.318 & 3,46 & 231.105 & 1,32 & 893.037 & 4,59 \\
\hline Outros & 139.666 & 0,59 & 126.105 & 0,52 & 210.685 & 0,96 & 885.540 & 5,04 & 467.876 & 2,40 \\
\hline Laboratório Enila & 99.730 & 0,42 & 532.143 & 2,20 & 219.581 & 1,00 & 0 & 0,00 & 0 & 0,00 \\
\hline Total & 23.646 .438 & 100,00 & 24.209 .139 & 100,00 & 22.035 .457 & 100,00 & 17.573 .536 & 100,00 & 19.470 .212 & 100,00 \\
\hline
\end{tabular}

* em US\$.

Fonte: Divisão de Estatísticas do Comércio Exterior, Ministério da Fazenda.

Figura 1

Participação dos principais produtores nas importações

do segmento privado. Brasil, 2001

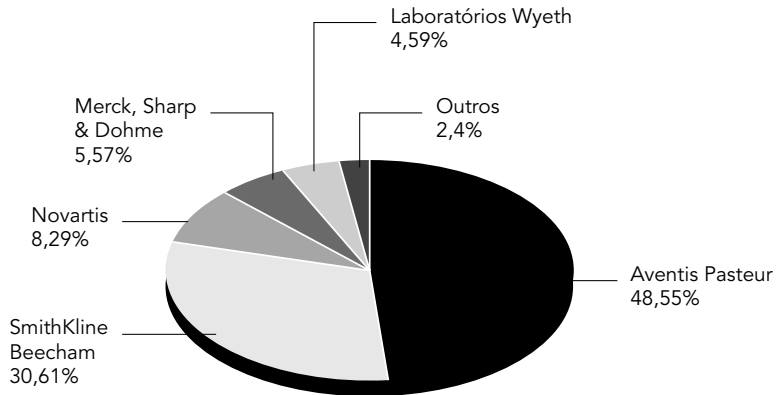

preço médio assim obtido foi multiplicado pelo número de doses de cada vacina importada naquele ano. Os resultados obtidos podem ser vistos na Tabela 5.

Com base na utilização desta metodologia de conformação deste segmento, o volume de recursos mobilizados alcança 170 milhões de reais. Isso é facilmente explicável considerando-se o preço médio praticado pelo mercado com a comercialização das vacinas. Apesar de trabalhar com um volume de doses muito inferior ao do PNI, o preço médio praticado no mercado por dose aplicada faz com que o montante de gastos com vendas atinja níveis consideráveis. Observa-se que a vacina contra influenza detém cerca de $32 \%$ do segmento em valores, seguida por um conjunto de vacinas modernas, entre elas hepatite A e A/B, varicela, a tríplice bacteriana acelular e a combinada pentavalente (DtaP+poliomielite+hib)

\section{O mercado brasileiro de vacinas: uma primeira caracterização}

A análise do segmento privado permite que se possa proceder a uma primeira aproximação à avaliação das dimensões do conjunto do mercado de vacinas, englobando os segmentos público e privado.

A caracterização do mercado total de vacinas a partir desta abordagem ganha outros contornos em termos de seu peso econômico no conjunto do complexo industrial da saúde. Se considerados, além do volume de recursos envolvidos na comercialização privada, aqui analisados, aqueles despendidos pelo PNI para a oferta no segmento público, pode-se obter uma visão global deste mercado no país.

A Tabela 6 permite analisar o mercado total, detalhando-o por tipo de vacina.

Desse modo, o mercado total alcançava em 2000, cerca de 396 milhões de reais, representando a participação do segmento privado $43 \%$ do total. Embora se tenha revelado grande a diferença no volume de doses utilizadas e, portanto, no número de pessoas cobertas em cada segmento, o preço praticado pelo mercado na venda direta dos produtos ao consumidor faz com que o volume de recursos mobilizados pelo segmento privado aproxime-se, em valores, daquele do segmento público.

A Tabela 6 permite também obter algumas análises singulares: 
Participação* dos produtores nas importações das principais vacinas para o segmento privado do mercado de vacinas. Brasil, 2001.

\begin{tabular}{|c|c|c|c|c|c|c|c|}
\hline Vacinas & Aventis & GlaxoSmithKline & Merck & Wyeth & Novartis & Outras & Total \\
\hline Influenza & 5.679 .015 & 2.807 .530 & & & 1.428 .908 & & 9.915 .453 \\
\hline Varicela & 927.503 & 797.391 & 296.316 & & & & 2.021 .210 \\
\hline DTP Acelular + pólio inativada + Hib & 569.763 & 817.875 & & & & & 1.387 .638 \\
\hline Hepatite A & 531.543 & 329.688 & 434.835 & & & & 1.296 .066 \\
\hline Pneumococo & 233.941 & & 123.333 & 893.037 & & & 1.250 .311 \\
\hline Hepatite A/B & & 893.537 & & & & & 893.537 \\
\hline Difteria/Tétano/Coqueluche & 672.066 & & & & & & 672.066 \\
\hline Hepatite B & & 254.117 & 202.929 & & & & 457.046 \\
\hline $\mathrm{Hib}$ & 446.662 & 2.828 & & & & & 449.490 \\
\hline Meningite $B / C$ & & & & & & 253.565 & 253.565 \\
\hline Poliomielite & 99.347 & 3.039 & & & 101.444 & & 203.830 \\
\hline Meningite $\mathrm{A} / \mathrm{C}$ & 189.567 & & & & & & 189.567 \\
\hline Dupla adulto & 3.782 & & & & 83.700 & & 87.482 \\
\hline Outras vacinas & & & & & & & 392.951 \\
\hline Total & 9.353 .189 & 5.906 .005 & 1.057 .413 & 893.037 & 1.614 .052 & 253.565 & 19.470 .212 \\
\hline
\end{tabular}

* em US\$.

Fonte: Divisão de Estatísticas do Comércio Exterior, Ministério da Fazenda.

- O segmento público respondeu pela totalidade de oferta das vacinas: dupla viral, febre amarela e raiva canina.

- A vacina BCG é totalmente fabricada no país pela Fundação Ataulfo de Paiva. Apesar de no ano de 2000 apenas $0,96 \%$ de sua produção ter se destinado ao mercado privado, sua participação em termos financeiros no conjunto do mercado é significativa.

- Predomínio absoluto do segmento privado em relação às vacinas contra hepatite $A$, hepatite $\mathrm{A} / \mathrm{B}$, tríplice bacteriana acelular, varicela, e as modernas combinadas. Ou seja, domínio completo do segmento privado na oferta dos produtos mais modernos disponíveis no mercado.

- O volume de recursos envolvidos na comercialização da vacina contra influenza atinge mais de 100 milhões anuais, sendo o volume de recursos mobilizados pelos dois segmentos praticamente o mesmo. Entretanto, enquanto o PNI imunizou em 2000 cerca de 14 milhões de pessoas, o segmento privado o fez em apenas cerca de 2,5 milhões.

- $\quad 97 \%$ dos valores mobilizados com o uso da vacina tríplice bacteriana acelular (DtaP) foram no segmento privado.

- O segmento privado ainda detém $43 \%$ do mercado para a vacina contra hepatite B.

- Vacinas tradicionais como a DPT e sarampo apresentam ainda significativa presença no segmento privado de oferta em termos de valores (em torno de 25\%).

- As vacinas modernas, considerando ambos os segmentos, representam em valores $73 \%$ do mercado brasileiro.

Estes dados exigem uma revisão não apenas do entendimento sobre o tamanho e dinâmica deste setor dentro do complexo da saúde, como também do expressivo volume de recursos mobilizados no interior do segmento privado. A Figura 2 compara o volume de vendas de algumas classes terapêuticas do mercado de medicamentos do Brasil, disponíveis para o ano de 1998, com o de vacinas para o ano de 2000. Com um volume de vendas de 396 milhões de reais para esse ano, o mercado de vacinas no Brasil apresentou dimensões próximas ao de analgésicos e praticamente idêntico ao de vitaminas, colocando-se como o quinto em termos de vendas, no conjunto do mercado farmacêutico.

Trata-se portanto, de um dos principais segmentos de mercado da indústria farmacêutica e possivelmente um dos maiores da industria biotecnológica do país na área da saúde.

\section{Conclusões}

A inserção tardia das vacinas no processo de mercantilização da saúde determinou que apenas recentemente fosse despertada a curiosi- 
Estimativa de vendas de vacinas no segmento privado do mercado de vacinas. Brasil, 2000.

\begin{tabular}{|c|c|c|c|c|}
\hline Vacinas 1 & $\begin{array}{l}\text { Número } \\
\text { de doses }\end{array}$ & $\begin{array}{c}\text { Preço médio } \\
\text { (mercado privado)2 }\end{array}$ & Total3 & $\%$ \\
\hline Influenza 4 & 2.558 .185 & 15 a 30 & 54.143 .000 & 31,8 \\
\hline Hepatite A/B & 246.590 & 92 & 22.686 .280 & 13,3 \\
\hline Hepatite $A^{5}$ & 280.846 & 75 & 21.063 .450 & 12,4 \\
\hline Varicela & 170.010 & 93 & 15.810 .930 & 9,3 \\
\hline $\mathrm{Hib}$ & 152.987 & 53 & 8.108 .311 & 4,7 \\
\hline Hepatite $B^{5}$ & 148.805 & 51 & 7.589 .055 & 4,4 \\
\hline DTP acelular + pólio inativada + Hib & 60.927 & 120 & 7.311 .240 & 4,3 \\
\hline Difteria/Tétano/Pertussis acelular & 108.025 & 66 & 7.129 .650 & 4,2 \\
\hline Meningite $\mathrm{B} / \mathrm{C}$ & 51.000 & 96 & 4.896 .000 & 2,9 \\
\hline Tríplice viral & 111.973 & 39 & 4.366 .947 & 2,5 \\
\hline Meningite $\mathrm{A} / \mathrm{C}$ & 80.557 & 53 & 4.269 .521 & 2,5 \\
\hline $\mathrm{BCG}$ & 145.396 & 20 & 2.907 .920 & 1,7 \\
\hline Tétano & 68.573 & 35 & 2.400 .055 & 1,4 \\
\hline Pneumococo & 42.991 & 45 & 1.934 .595 & 1,1 \\
\hline $\mathrm{DTP}+\mathrm{Hib}$ & 25.335 & 50 & 1.266 .750 & 0,7 \\
\hline Tríplice bacteriana / DTP & 39.050 & 28 & 1.093 .400 & 0,6 \\
\hline Pneumococo conjugada & 6.000 & 170 & 1.020 .000 & 0,6 \\
\hline Sarampo & 25.023 & 36 & 900.828 & 0,5 \\
\hline Raiva & 5.990 & 88 & 527.120 & 0,3 \\
\hline Dupla bacteriana & 8.520 & 35 & 298.200 & 0,2 \\
\hline Rubéola & 5.000 & 34 & 170.000 & 0,1 \\
\hline Poliomielite (OPV) & 15.789 & 10 & 157.890 & 0,1 \\
\hline Cachumba & 2.490 & 34 & 84.660 & 0,05 \\
\hline Total & & & 170.135 .802 & 100 \\
\hline
\end{tabular}

1 Vacinas adquiridas pela população fora dos serviços públicos em clínicas, consultórios, hospitais ou fornecidas por empresas a seus funcionários.

2 Preço médio estimado com base em levantamento nas nove principais clínicas da Cidade de São Paulo.

3 Em Reais (R\$).

4 Considerando que $60 \%$ das doses destinaram-se a empresas e $40 \%$ à demanda individual.

Para empresas trabalhou-se com preço médio de $R \$ 15,00$ por dose. O restante a $R \$ 30,00$ por dose.

5 Considerou-se a média dos preços das apresentações pediátricas e de adultos.

Fonte: Divisão de Estatísticas do Comércio Exterior e Pesquisa de Campo.

dade de pesquisadores e instituições governamentais na procura de melhor compreensão de sua dinâmica. A organização de espaços privados para a oferta de vacinas é um fato que exige reflexões sobre a presença do setor público como um todo, no campo da saúde. A construção de um sistema misto como o brasileiro, em que formas privadas de organização do cuidado para segmentos específicos da população, convivem com a oferta estabelecida pelo SUS, parecem criar crescentes e complexos espaços de restrição ao acesso universal e equânime a serviços e produtos (Almeida, 1998). A análise aqui desenvolvida permite estender essa tendência ao campo da política de imunizações e ao espaço das políticas de prevenção.

A análise realizada deste segmento permite observar:
- O processo de inserção das práticas privadas de consumo de vacinas no país, que tem início nos anos 70, é alcançado pela dinâmica de mercantilização do setor saúde apenas no final dos anos 80;

- A considerável capilaridade da rede de pontos de venda desse segmento incluindo clínicas especializadas, consultórios, hospitais e empresas;

- O processo de estruturação deste segmento guarda íntimas relações com o desenvolvimento do PNI e das políticas públicas neste campo; - Apesar da cobertura populacional ser baixa em relação à alcançada pelo PNI, o volume de recursos mobilizados pelo segmento privado é semelhante àquele despendido pelo PNI;

- O mercado brasileiro de vacinas é dominado pelas duas empresas farmacêuticas multi- 
Mercado nacional de vacinas. Brasil, 2000.

\begin{tabular}{|c|c|c|c|c|c|}
\hline \multirow[t]{2}{*}{ Vacinas } & \multicolumn{2}{|c|}{ Segmento público 1} & \multicolumn{2}{|c|}{ Segmento privado2 } & \multirow{2}{*}{$\begin{array}{c}\text { Total } \\
\mathrm{R} \$\end{array}$} \\
\hline & $\mathrm{R} \$$ & $\%$ & $\mathrm{R} \$$ & $\%$ & \\
\hline Influenza & 47.732 .000 & 46,9 & 54.143 .000 & 53,1 & 101.875 .000 \\
\hline Haemophillus influenzae B & 66.471 .000 & 89,1 & 8.108 .311 & 10,9 & 74.579 .311 \\
\hline Tríplice viral & 25.316 .000 & 85,3 & 4.366 .947 & 14,7 & 29.682 .947 \\
\hline Hepatite A/B & & 0,0 & 22.686 .280 & 100,0 & 22.686 .280 \\
\hline Hepatite A & 88.000 & 0,4 & 21.063 .450 & 99,6 & 21.151 .450 \\
\hline Varicela & 4.858 .000 & 23,5 & 15.810 .930 & 76,5 & 20.668 .930 \\
\hline Hepatite B & 10.067 .000 & 57,0 & 7.589 .055 & 43,0 & 17.656 .055 \\
\hline Outras 3 & 14.941 .000 & 100,0 & & 0,0 & 14.941 .000 \\
\hline Dupla VIRAL & 12.096 .000 & 100,0 & & 0,0 & 12.096 .000 \\
\hline Poliomielite & 10.488 .000 & 98,5 & 157.890 & 1,5 & 10.645 .890 \\
\hline Pneumococo & 7.979 .000 & 80,5 & 1.934 .595 & 19,5 & 9.913 .595 \\
\hline Febre amarela & 9.200 .000 & 100,0 & & 0,0 & 9.200 .000 \\
\hline DTP acelular + pólio inativada + Hib & & 0,0 & 7.311 .240 & 100,0 & 7.311 .240 \\
\hline Tríplice bacteriana acelular / DtaP & 211.000 & 2,9 & 7.129 .650 & 97,1 & 7.340 .650 \\
\hline $\mathrm{BCG}$ & 4.270 .000 & 59,5 & 2.907 .920 & 40,5 & 7.177 .920 \\
\hline Meningite $\mathrm{A} / \mathrm{C}$ & 992.000 & 18,9 & 4.269 .521 & 81,1 & 5.261 .521 \\
\hline Meningite $B / C$ & & 0,0 & 4.896 .000 & 100,0 & 4.896 .000 \\
\hline Tríplice bacteriana/DTP & 3.622 .000 & 76,8 & 1.093 .400 & 23,2 & 4.715 .400 \\
\hline Dupla bacteriana & 3.344 .000 & 91,8 & 298.200 & 8,2 & 3.642 .200 \\
\hline Sarampo & 2.250 .000 & 71,4 & 900.828 & 28,6 & 3.150 .828 \\
\hline Raiva & 2.243 .000 & 81,0 & 527.120 & 19,0 & 2.770 .120 \\
\hline Tétano & & & 2.400 .055 & 100,0 & 2.400 .055 \\
\hline $\mathrm{DTP}+\mathrm{Hib}$ & & 0,0 & 1.266 .750 & 100,0 & 1.266 .750 \\
\hline Pneumococo conjugada & & 0,0 & 1.020 .000 & 100,0 & 1.020 .000 \\
\hline Rubéola & & 0,0 & 170.000 & 100,0 & 170.000 \\
\hline Caxumba & & 0,0 & 84.660 & 100,0 & 84.660 \\
\hline Total & 226.168 .000 & 57,0 & 170.135 .802 & 43,0 & 396.303 .802 \\
\hline
\end{tabular}

1 Inclui o total de gastos com aquisições de vacinas para o ano de 2000 pelo Ministério da Saúde.

2 Calculado tomando-se como base o número de doses de cada vacina importada no ano e multiplicada pelo preço médio do mercado, obtida por meio de pesquisa junto as nove principais clínicas da Cidade de São Paulo.

3 Inclui a aquisição da vacina anti-rábica canina no valor de $\mathrm{R} \$ 14.665 .000,00$.

Fontes: Programa Nacional de Imunização e Divisão de Estatísticas do Comércio Exterior, Ministério da Fazenda.

nacionais que, atualmente, implementam em conjunto com os dois principais produtores estatais (Biomanguinhos e Butantan) contratos de transferência de tecnologia (Temporão, 2002);

- A estruturação e consolidação do segmento, suas relações estruturais com o setor privado de oferta de serviços médico-hospitalares introduzem a lógica mercantil em espaço "nobre" das políticas públicas do setor saúde.

A caracterização do segmento privado do mercado de vacinas foi desenvolvida por meio de um esforço de sistematização e da inter-relação entre os vários atores e instituições na dinâmica do mercado. Com base na análise das inter-relações entre os vários atores e da dinâmica de atuação deste segmento, pode-se perceber a complexidade do sistema, que apresen- ta relações de interdependência, com o Estado ocupando um papel de grande capacidade indutora.

No caso do segmento privado, os grandes produtores multinacionais, por meio de suas filiais aqui estabelecidas, fornecem os produtos que vão movimentar este segmento, fruto do desenvolvimento de suas atividades de P\&D e de seus esforços de marketing. Suas filiais, por intermédio de distintas estratégias de comercialização, fornecem os produtos principalmente a distribuidores e clínicas de vacinação. No caso destas, "existe uma tendência para o estabelecimento de relações entre fabricantes e clínicas que tendem para a exclusividade em troca de vantagens como descontos, apoio de vendas etc." (I. Benevides, entrevista). As filiais multi- 
Figura 2

Volume de vendas de algumas classes terapêuticas

de medicamentos e de vacinas. Brasil.

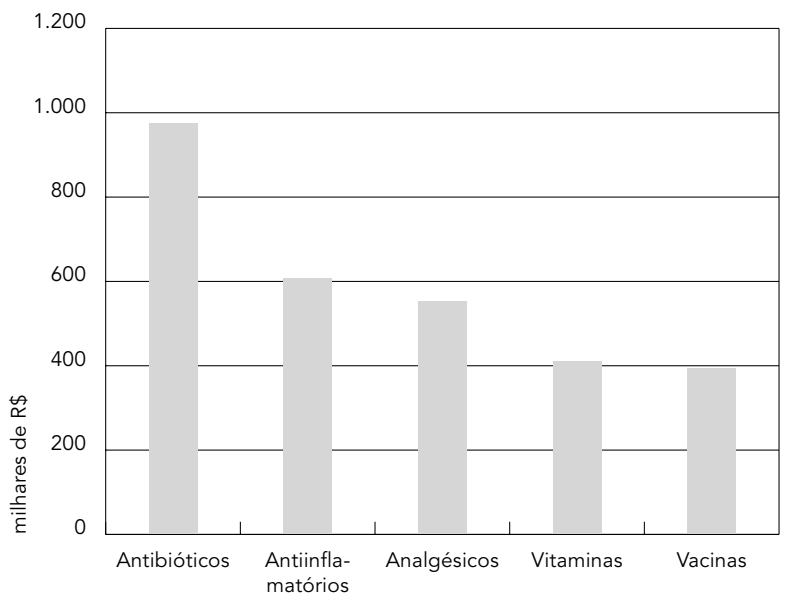

Fonte: Frenkel (2001) para 1998 e pesquisa de campo para 2000

Nota: Os dados para medicamentos referem-se ao ano de 1998 e para vacinas ao de 2000. Os valores referentes a medicamentos foram convertidos para Real utilizando-se a taxa média do banco de dados do Banco Central do Brasil. Os valores foram atualizados para o ano de 2000 pela média do Índice de Preços ao Consumidor do IBGE.
Evidencia-se que a dinâmica do mercado ao estabelecer relações e fluxos obedece à lógica implícita no ciclo de vida dos distintos produtos e à estratégia de preços administrados pelos produtores centrais. Nas fases de lançamento e de penetração no mercado, quando predominam poucos produtores (normalmente apenas um) e altos preços, os produtos encontrados e utilizados nos países centrais, são oferecidos apenas no segmento privado. Já na fase de maturidade, quando a entrada de vários produtores leva à redução dos preços, os produtos são incorporados ao PNI e utilizados em larga escala. Nesta fase de "deslocamento", o segmento privado incorpora novos produtos, ainda em fase de lançamento ou de penetração no mercado, além de manter para os produtos maduros nichos de mercado cujas características estão determinadas pela maior ou menor abrangência da política de universalização desenvolvida pelo PNI (Temporão, 2002).

O fato é que o PNI, por restrições orçamentárias, não pode disponibilizar aos usuários do SUS, desde o início, produtos eficazes e disponíveis no mercado, enquanto o segmento privado os oferece aos que podem pagar diretamente pelos mesmos produtos. Este tipo de restrição ao acesso das novas tecnologias disponibilizadas em outras áreas do diagnóstico ou terapia, não parece ter paralelo no interior do SUS, onde apenas os procedimentos considerados experimentais apresentam restrições ao acesso.

A SOPERJ evidencia uma visão dividida em relação ao exercício da vacinação em consultórios.

“É política da Sociedade Brasileira de Pediatria defender o direito dos pediatras de vacinarem em seus consultórios. Entretanto, é necessário que se fiscalize o cumprimento da portaria conjunta número 1 da ANVISA e FUNASA, referente aos estabelecimentos privados. A fiscalização praticamente inexiste" (SOPERJ, entrevista).

Outro depoimento, obtido junto à diretoria da SOPERJ, reforça o apoio à prática em clínicas especializadas mas, no caso dos consultórios, "somos formalmente contra, pois neles não há um controle quanto à conservação e validade das vacinas...sabe-se que a rede de frio é negligenciada em várias situações, e parece ser mais falha em consultórios particulares".

De todo modo, a SOPERJ vê a oferta privada como um fator positivo dentro do sistema de saúde: "as clínicas de vacinas, assim como os consultórios, desde que cumpram a legislação, exercem papel complementar ao do PNI disponibilizando vacinas ainda não existentes no PNI e que são recomendadas pela Sociedade Brasileira de Pediatria, vacinas de tecnologia mais 
recente, combinações etc. A nosso ver geram demanda da população pela ampliação dos serviços nos centros de saúde, o que a longo prazo, gera mais benefícios no campo das imunizações. O papel do pediatra ou outro médico no setor privado é indispensável porque há um grande desenvolvimento técnico e científico na área, demandando aquisição e difusão desses conhecimentos para manter um atendimento atualizado e de melhor qualidade".

Nessa visão, a oferta de produtos modernos na rede privada cumpriria um papel indutor sobre a rede pública por intermédio da pressão da população pela inclusão desses produtos ao PNI. Como visto, a lógica em que o mercado opera é pouco sensível a estas pressões obedecendo particularmente aos princípios que regem a dinâmica concorrencial.

O crescimento da presença de serviços privados em espaços até então de hegemonia pública exige uma reflexão sobre as repercussões

\section{Referências}

ALMEIDA, C. M., 1988. O Mercado Privado de Serviços de Saúde no Brasil: Panorama Atual e Tendências da Assistência Médica Suplementar. Textos para Discussão 599. Brasília: Instituto de Pesquisa Econômica Aplicada.

BENCHIMOL, J. \& TEIXEIRA, L. A., 1993. Cobras, Lagartos e Outros Bichos: Uma História Comparada dos Institutos Oswaldo Cruz e Butantan. Rio de Janeiro: Editora UFRJ.

BRAGA, J. C. S. \& SILVA, P. L. B., 2001. A mercantilização admissível e as políticas públicas inadiáveis: Estrutura e dinâmica do setor saúde no Brasil. In: Brasil: Radiografia da Saúde (B. Negri \& G. Giovanni, org.), pp. 19-42, Campinas: Editora da Unicamp.

CORDEIRO, H., 1980. A Indústria da Saúde no Brasil. São Paulo: Edições Graal.

FERNANDES, T. M., 1999. Vacina Antivariólica: Ciência, Técnica e o Poder dos Homens. Rio de Janeiro: Editora Fiocruz.

GADELHA, C. \& TEMPORÃO, J. G., 1999. A Indústria de Vacinas no Brasil: Desafios e Perspectivas. Rio de Janeiro: Banco Nacional de Desenvolvimento Econômico e Social. econômicas e técnicas dos distintos aspectos envolvidos nesse processo. Entretanto, essa análise deve envolver também as repercussões políticas. À trajetória aqui analisada somam-se fenômenos presentes em outros espaços da assistência à saúde, caracterizando uma crescente fragilização da presença do Estado e de restrição ao acesso a bens e serviços garantidos constitucionalmente.

A dinâmica aqui estabelecida, as relações entre os dois segmentos e o volume de recursos envolvidos demonstram a penetração de lógicas e práticas comerciais em um espaço até então de total hegemonia do poder público. A tendência aqui demonstrada de um processo em curso de introdução da mercantilização nas práticas de prevenção, parece apontar para o fortalecimento da lógica e dinâmica capitalistas no interior do sistema de saúde brasileiro, ampliando seus espaços de influência e de capacidade de direcionamento de práticas e processos.
GRECO, M., 2002. The future of vaccines: An industrial perspective. Vaccine, 20:S101-S103.

MS (Ministério da Saúde), 1978. Parecer da consultoria jurídica de no 4-108, de 1978. Diário Oficial da União, 17 jul.

NEGRI, B. \& GIOVANNI, G. (org.), 2001. Brasil: Radiografia da Saúde. Campinas: Editora da Unicamp.

RIBEIRO, M. A. R., 2001. Saúde pública e as empresas químico-farmacêuticas. História, Ciências, Saúde - Manguinhos, 7:607-626.

SES-SP (Secretaria de Estado de Saúde de São Paulo), 1977. Resolução SS no 42, de 12 de outubro de 1977. São Paulo: SES-SP.

TEMPORÃO, J. G., 2002. O Complexo Industrial da Saúde: Público e Privado na Produção e Consumo de Vacinas no Brasil. Tese de Doutorado, Rio de Janeiro: Instituto de Medicina Social, Universidade do Estado do Rio de Janeiro.

Recebido em 12 de setembro de 2002

Versão final reapresentada em 19 de fevereiro de 2003 Aprovado em 8 de maio de 2003 